Division of Geological \& Geophysical Surveys

PRELIMINARY INTERPRETIVE REPORT 2016-5

INVESTIGATION OF RARE-EARTH ELEMENTS AND ZIRCONIUM IN THE NORTHERN WINDY FORK PERALKALINE PLUTON, WEST-CENTRAL ALASKA

by

James C. Barker

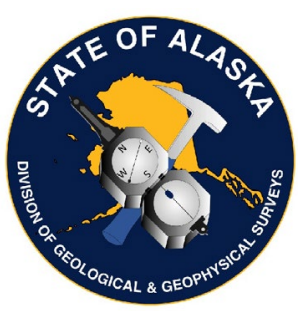

June 2016

Released by

STATE OF ALASKA

DEPARTMENT OF NATURAL RESOURCES

Division of Geological \& Geophysical Surveys

3354 College Rd., Fairbanks, Alaska 99709-3707

Phone: (907) 451-5010 Fax (907) 451-5050

dggspubs@alaska.gov

www.dggs.alaska.gov 



\section{CONTENTS}

Introduction

Logistics

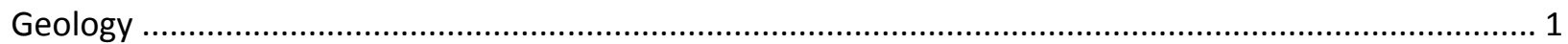

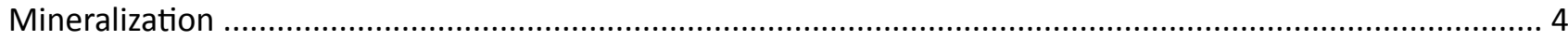

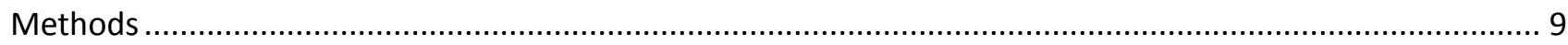

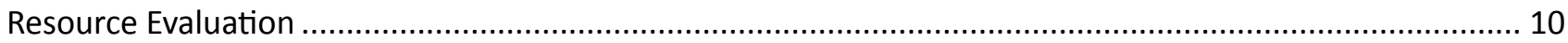

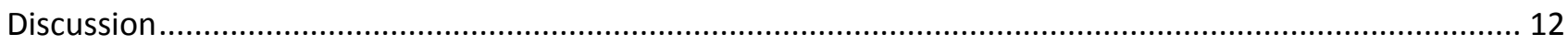

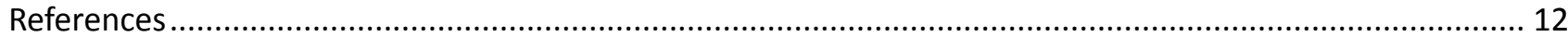

FIGURES

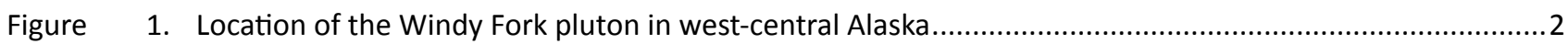

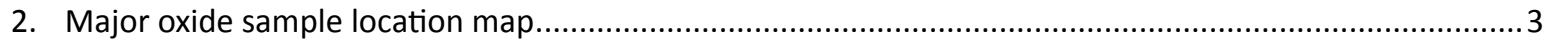

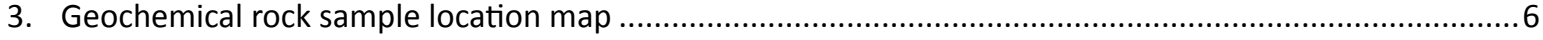

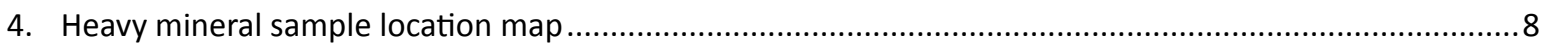

5. Map of outwash fan with bulk gravel sample locations and panned heavy mineral sample locations .......10

6. Photograph showing light-colored glaciofluvial outwash fan derived from the northern half of the

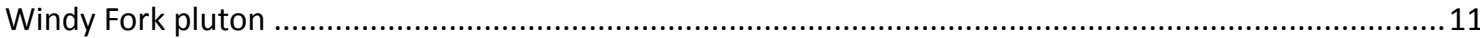

\section{TABLES}

Table 1. Normalized major oxide and CIPW norms, samples from Windy Fork pluton and plutonic float

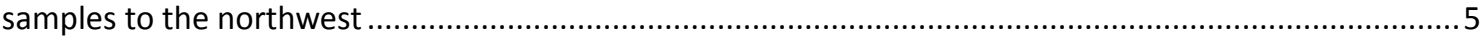

2. Analyses (in ppm) of pan concentrates from the Windy Fork pluton and vicinity .....................................7

3. Resource evaluation of the alluvial outwash fan, Windy Fork pluton .........................................................

\section{APPENDICES}

Appendix A. Multi-element analyses of rock samples from the northern Windy Fork Pluton area.............................13

B. Analytical Report 4343E9s ................................................................................................................ 
Units of measure abbreviations used in this report

$\begin{array}{ll}\text { cps } & \text { count per second } \\ \mathrm{ft} & \text { foot, feet } \\ \mathrm{g} & \text { gram } \\ \mathrm{in} & \text { inch } \\ \text { long } & \text { longitude } \\ \text { lat } & \text { latitude } \\ \mathrm{lb} & \text { pound } \\ \mathrm{lb} / \mathrm{yd} & \text { pounds per cubic yard } \\ \mathrm{mi} & \text { mile } \\ \mathrm{Ma} & \text { million years } \\ \mathrm{pct} & \text { percent } \\ \mathrm{ppm} & \text { parts per million } \\ \mu \mathrm{m} & \text { micrometer, micron } \\ \mathrm{st} & \text { short ton } \\ \mathrm{yd} & \text { cubic yard }\end{array}$




\title{
INVESTIGATION OF RARE-EARTH ELEMENTS AND ZIRCONIUM IN THE NORTHERN WINDY FORK PERALKALINE PLUTON, WEST-CENTRAL ALASKA
}

\author{
by \\ James C. Barker ${ }^{1}$
}

\begin{abstract}
The northern Windy Fork peralkaline pluton was investigated as part of the U.S. Bureau of Mines Strategic and Critical Minerals Program in Alaska. The pluton is about 85 miles south of McGrath, west-central Alaska. Relatively abundant ilmenite, zircon, and rare-earth-element-bearing minerals are liberated by glacial scour and frost fracturing of granitic bedrock and concentrated in glaciofluvial outwash features. An outwash fan is estimated to contain 17 million yds $^{3}$ or more at a sub-economic grade of 20-25 lbs/ $\mathrm{yd}^{3}$ of heavy minerals based on surface samples. No subsurface sampling was possible at the time.

The heavy minerals are derived from peralkaline plutonic rocks where they occur as widely disseminated accessory minerals. No evidence was found, either in situ or in float, to indicate significant mineralization occurs as potentially economic lode deposits in the pluton. The northern Windy Fork pluton is deeply eroded and mostly lacking mappable, late-state, volatile-rich hydrothermal fluids or magmas.
\end{abstract}

\section{INTRODUCTION}

In July 1988, the U.S. Bureau of Mines (USBM) conducted a reconnaissance-level investigation of the northern Windy Fork pluton located in the McGrath A-3 Quadrangle (fig. 1). The pluton extends south into the Lime Hills D-3 and D-4 quadrangles, but due to logistical constraints it was not possible to include the Lime Hills area. The project was performed in cooperation with the Alaska Division of Geological \& Geophysical Surveys (DGGS), which provided helicopter support and the geological assistance of D.N. Solie. Ten days were spent in the field for the purpose of determining estimated grade-per-unit-volume values for samples containing niobium, titanium, rare-earth elements (REE), yttrium, zirconium, and other associated lithophile elements.

This project was undertaken to follow up on previous studies that indicated the possibility of uranium and REE occurrences in the pluton area. Reed and Miller (1980) reported radioactive zones and anomalous U-Th values in the granite and originally observed the compositional similarity between the Windy Fork and Bokan Mountain plutons. Sampling by Gilbert and Solie (1983) and Solie (1983) of the McGrath A3 Quadrangle showed that the Windy Fork pluton has a peralkaline composition not unlike that of Bokan Mountain in Southeast Alaska, where extensive REE mineral deposits are known (Solie, 1983; Warner and Barker, 1989). There have been no reported mineral discoveries in the Windy Fork area by private industry.

\section{LOGISTICS}

The study area was accessed by helicopter in July 1988 from the village of McGrath, which is about 85 air miles north of the Windy Fork pluton. A camp was set up at the confluence of a small stream draining the Windy Fork pluton, and the Windy Fork River (fig. 2) at an elevation of 2,900 ft. Campsites are best placed along the lower portions of side tributaries, where some protection is afforded from the valley winds.

There are several private cabins in the area with short, unimproved airstrips, which could provide future access with permission. The Windy Fork River is cautiously navigable, and an inflatable canoe was used to move to a second spike camp location.

The perimeter of the pluton can be reached on foot along various creeks that drain the central glacial ice and along several ridges that reach up to the contact. Access to the interior of the pluton, which is largely covered in ice, requires mountaineering experience.

\section{GEOLOGY}

The Windy Fork pluton intrudes the Dillinger terrane, which locally comprises limestone, shale, and volcaniclastic rocks. Local geology was mapped at 1:63,360 scale by Gilbert and Solie (1983). The pluton is indicated to be Tertiary age; two $\mathrm{K}-$ Ar dates $(30.1 \pm 0.9 \mathrm{Ma}$ and 29.0 $\pm 0.9 \mathrm{Ma})$ were reported by Reed and Lanphere (1972).

\footnotetext{
${ }^{1}$ Cathedral Rock Enterprises, LLC, PM Box 145, 3875 Geist Rd. Suite E, Fairbanks, Alaska 99709; jcbarkergeo@gmail.com
} 


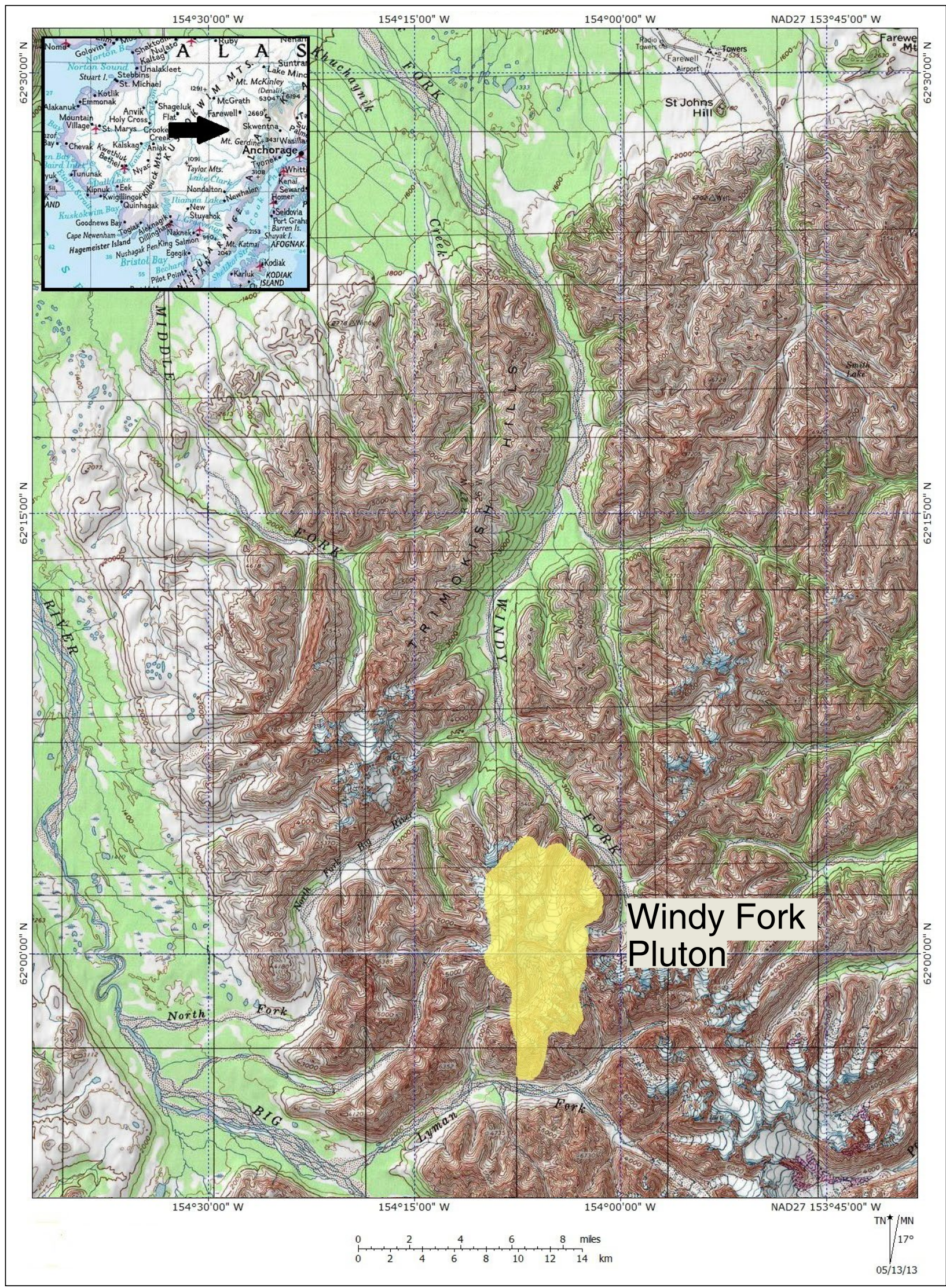

Figure 1. Location of the Windy Fork pluton in west-central Alaska. 


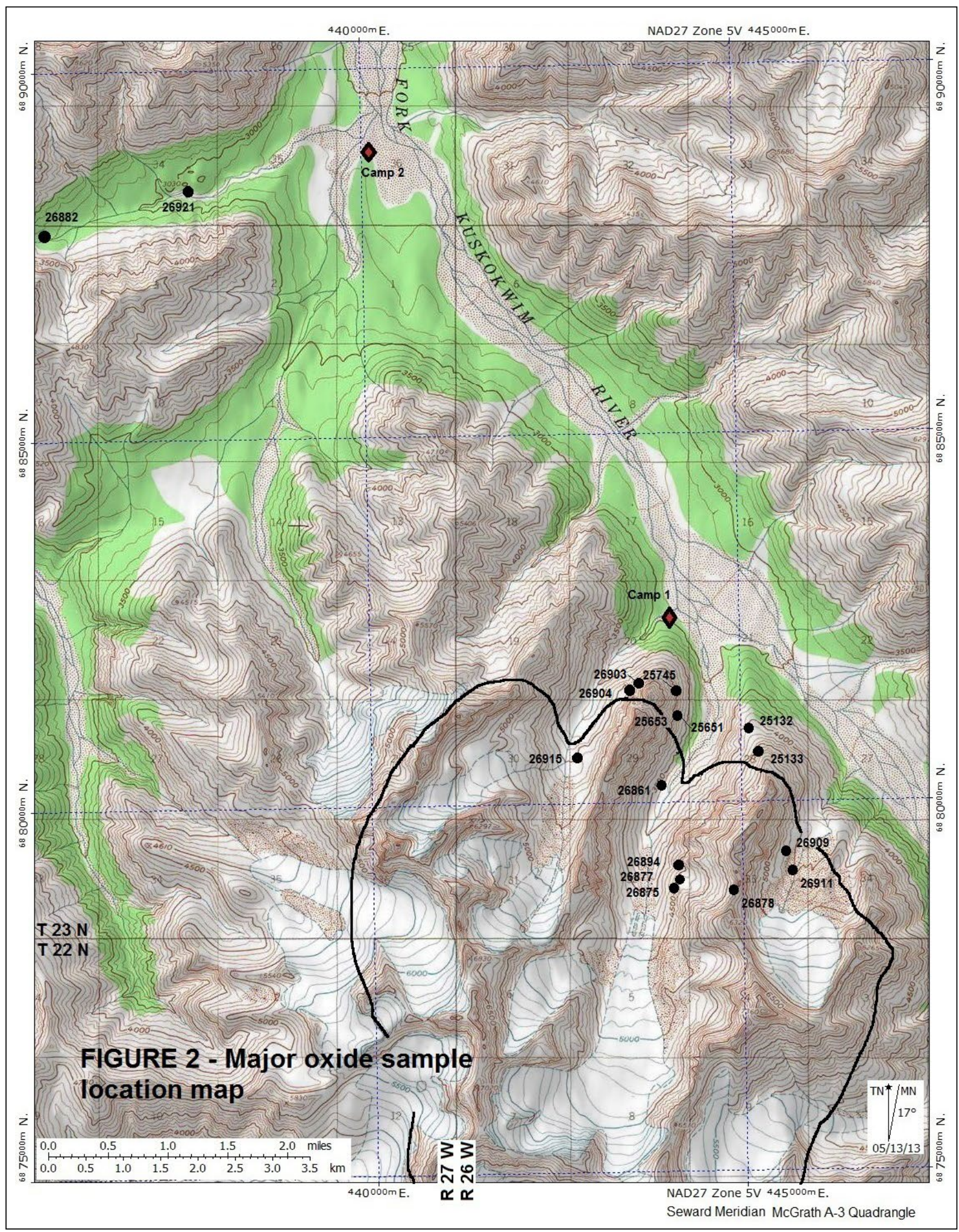

Figure 2. Major oxide sample location map. Red diamonds with black outlines mark the locations of camps used during fieldwork; black dots with sample numbers show sample locations. Black line records approximate north margin of the Windy Fork pluton. Sample descriptions and analytical data are listed in table 1, except for sample number 26903 which was collected for trace-element geochemistry and is presented in appendix A and 25653 which is a pan concentrate sample and are presented in table 2. 
The Windy Fork pluton is almost entirely composed of riebeckite granite, with subtle color variations on weathered surfaces. Minor amounts of riebeckite-biotite granite were found, but only in float. In the northern portion of the pluton examined in this study, there are no coarse-grained phases, little aplite, and no syenite or gabbro such as was reported at the Middle Fork pluton nearby (Gilbert and Solie, 1983; Solie, 1983).

The chemical composition of the pluton is generally peralkaline granite. Table 1 lists the oxide percentages, CIPW norms, and sample descriptions for representative rock samples collected from phases of the Windy Fork pluton. Peralkaline granite of unknown extent was also found 5 miles northwest of the pluton (sample KS26882; fig. 2). Additional rock samples (fig. 3) were collected for multi-element analyses and results are presented in Appendix A.

The Windy Fork pluton characteristically exhibits a high radiometric response. Readings taken along foot traverses, using a handheld scintillometer, generally ranged from 600 to 800 counts per second (cps), which is two to three times normal background encountered in Alaska granitic rocks by the author.

Only one relatively small area of differentiated, late-stage intrusive rocks was found. The area forms a crude $\mathrm{E}-\mathrm{W}$ zone through the central portions of Sections 32 and 33, T23N, R26W, Seward Meridian, and is variably iron-stained. In this area, narrow pegmatite pods, which registered up to 4,000 cps, are present (sample KS26867; fig. 3), as are units of limonitic biotite aplite, fine-grained riebeckite-biotite granite, and rhyolite. Pegmatites are podiform shaped and do not exceed 10 to $20 \mathrm{ft}$ in their longest dimension. The zone is also characterized by an overall higher radiometric background (about 2 times normal) compared to the riebeckite granite elsewhere in the pluton. A fine- to medium-grained riebeckite granite phase found in the zone near the ridge crest of Sec. 33 typically ranges from 900 to 2,000 cps. Minor disseminated accessory allanite and monazite have been tentatively identified to be the cause of the radioactivity (see KS26878 and KS26895, fig. 3, appendix A).

The Windy Fork pluton has been cut by basalt, andesite porphyry, and aplite dikes. One agpaitic dike containing eudialyte was noted by Reed and Miller (1980) (see KS25743 and KS26907-KS26908, fig. 3, appendix A) and further characterized as a REE-poor eudialyte by Johnson and others (1990). It intrudes the Windy Fork pluton and was found to be $2 \mathrm{ft}$ wide, but could be traced for only $30 \mathrm{ft}$. A chip sample (KS25743) from the eudialyte dike contained 0.49 percent $\mathrm{Zr}$ but no appreciable REE (for example, $\mathrm{Ce}=131$ parts per million $[\mathrm{ppm}]$ ). Sample descriptions and multi-element analytical results from dikes and differentiated zones in the Windy Fork pluton are recorded in Appendix A. Quality control check assays and expanded REE analyses are found in Appendix B.

The Windy Fork granite has a narrow contact zone, generally no more than $200 \mathrm{ft}$ wide, where variable fine-grained textures and silicified zones occur. Country rock has been recrystallized near the intrusive contact, but no skarn-bearing material was noted in situ or in creek float. Hornfels and silicification extends relatively short distances from the contact.

At several locations dikes radiate from within or near the main intrusive body into country rock, however, their relationship to the pluton, if any, was not evident. Dike composition ranges from rhyolite to pyroxenite. The texture is generally fine grained, and the dikes dip almost or close to vertical. Rhyolitic dikes are slightly radioactive; the more mafic dikes are iron-stained from finely disseminated pyrite and pyrrhotite.

\section{MINERALIZATION}

Mineralized bedrock in the plutonic complex is limited to small, discontinuous pegmatite pods of little apparent economic interest. However, extensive glacial scouring of the pluton may have formed alluvial placer deposits of heavy minerals in streams draining the Windy Fork pluton. First-order streambeds and fan deposits draining the plutonic rocks contain unusually abundant concentrations of heavy minerals (table 2, fig. 4), and natural bands of black sand are common wherever finer fluvial sediments have accumulated. Natural surface accumulations or bands of heavy minerals, including the immediate outfall at the front (snout) of glacial ice, are noticeably radioactive (up to $600 \mathrm{cps}$ ) from contained allanite and thorite. Heavy mineral concentrates are composed of up to 50 percent magnetite and ilmenite with additional zircon and monazite. Heavy mineral grains all passed through 16 mesh screen during field screening and are visually estimated to be less than 35 mesh or finer in size.

At least 4,000 ft of incised vertical relief is present in the Windy Fork pluton from glacial scouring, indicating that massive amounts of granite have been removed. As typified by sample KS26865, taken at the base of a cirque glacier, abundant heavy minerals are present in the fine-grained fraction of recently deposited glacial sediment. Conversely, pan sampling in creeks draining only the surrounding sedimentary rocks showed no appreciable concentrations of heavy minerals (for example, KS25136). 


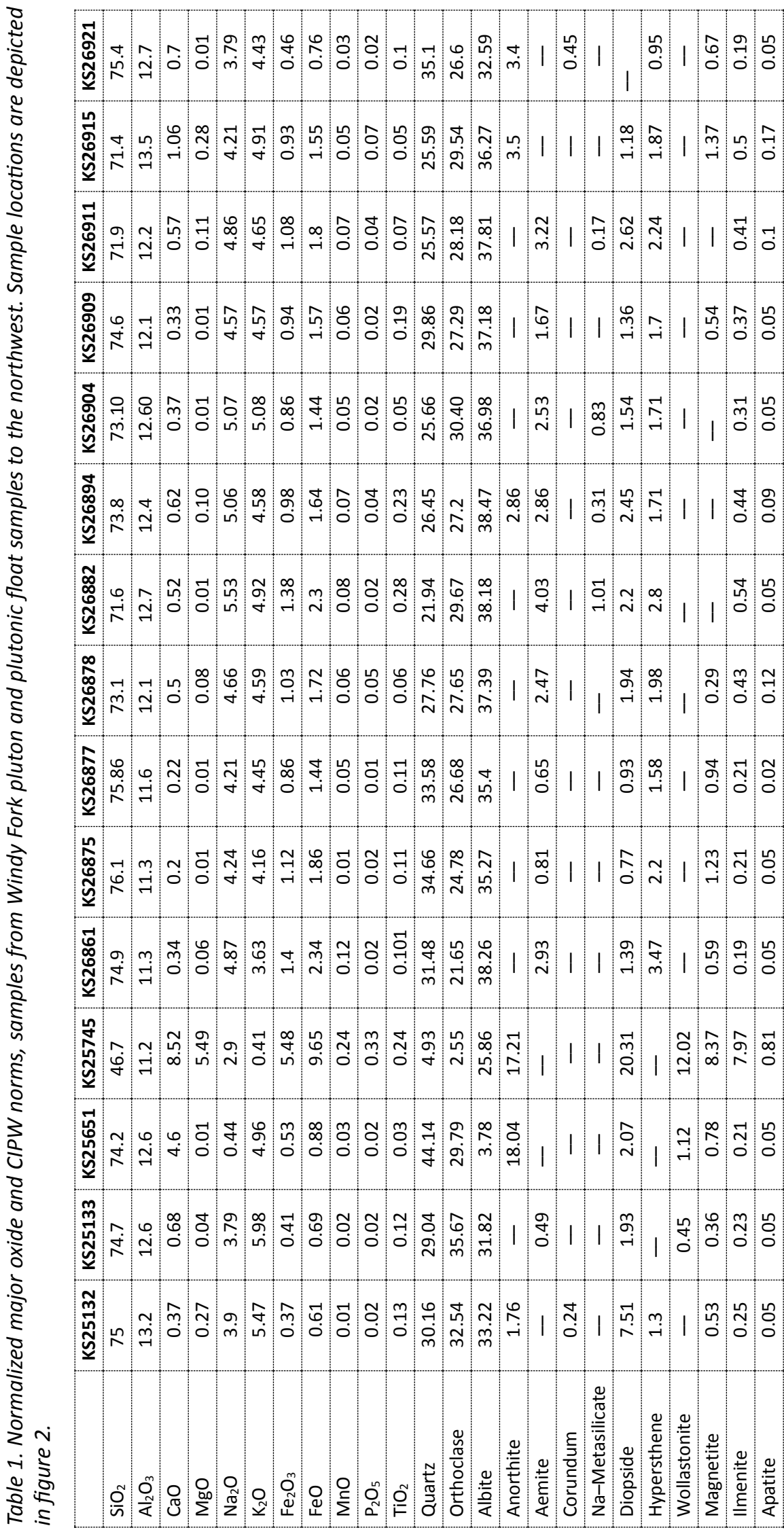

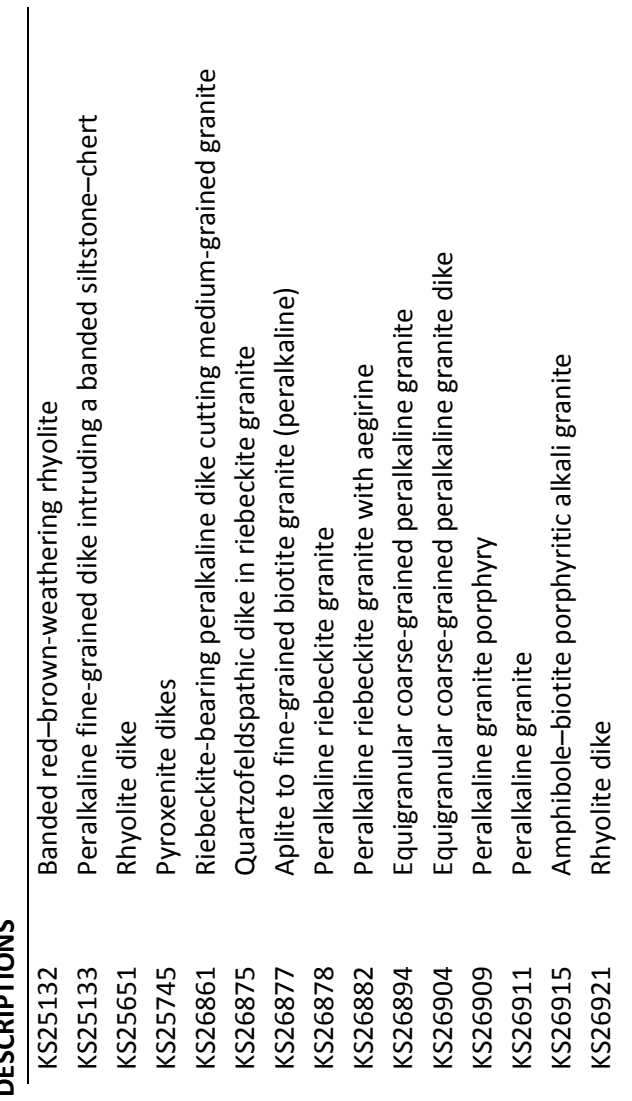




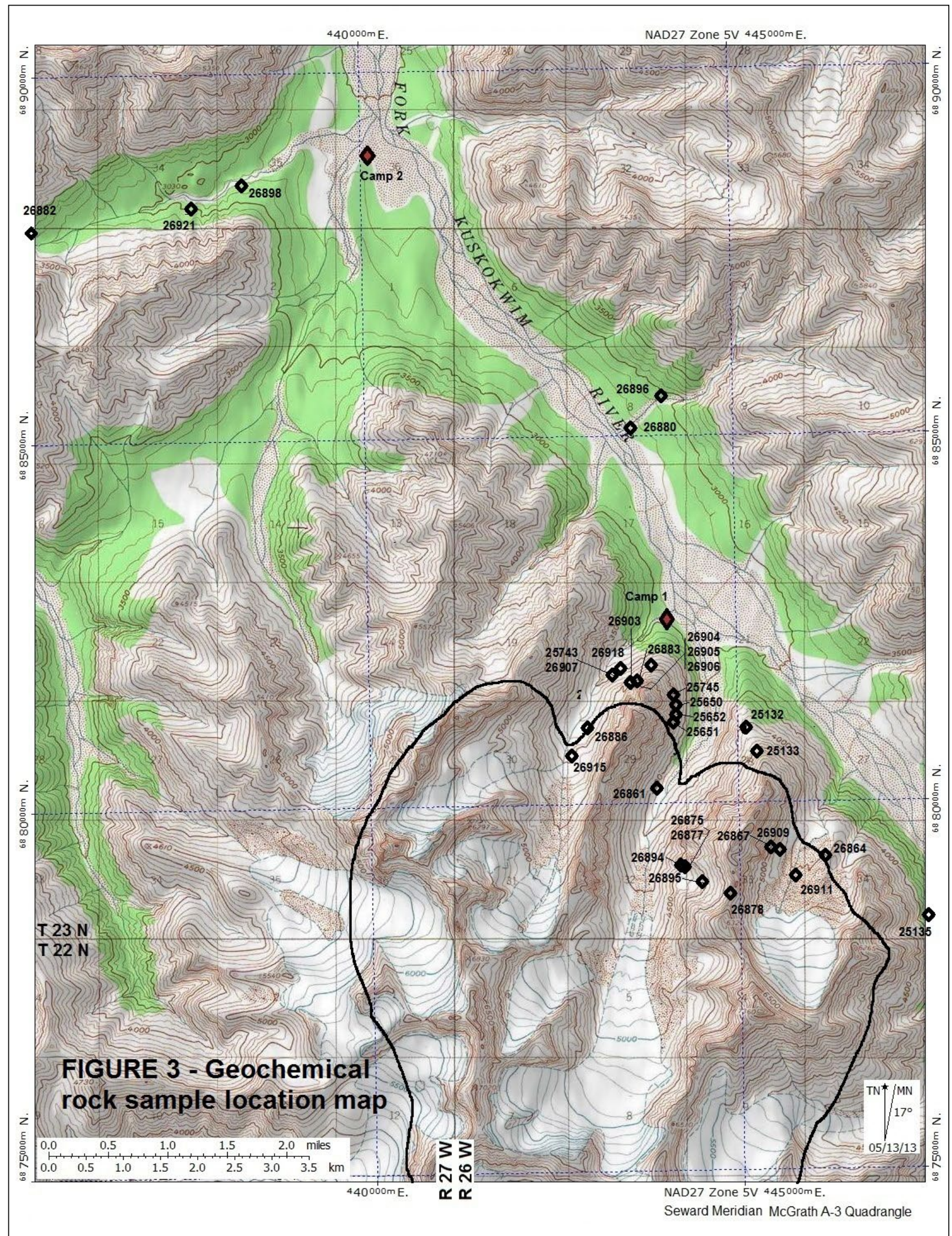

Figure 3. Geochemical rock sample location map. Red diamonds with black outlines mark the locations of camps used during fieldwork; empty black diamonds with sample numbers show sample locations. Black line records approximate north margin of the Windy Fork pluton. Sample descriptions and analytical data are listed in Appendix A. 

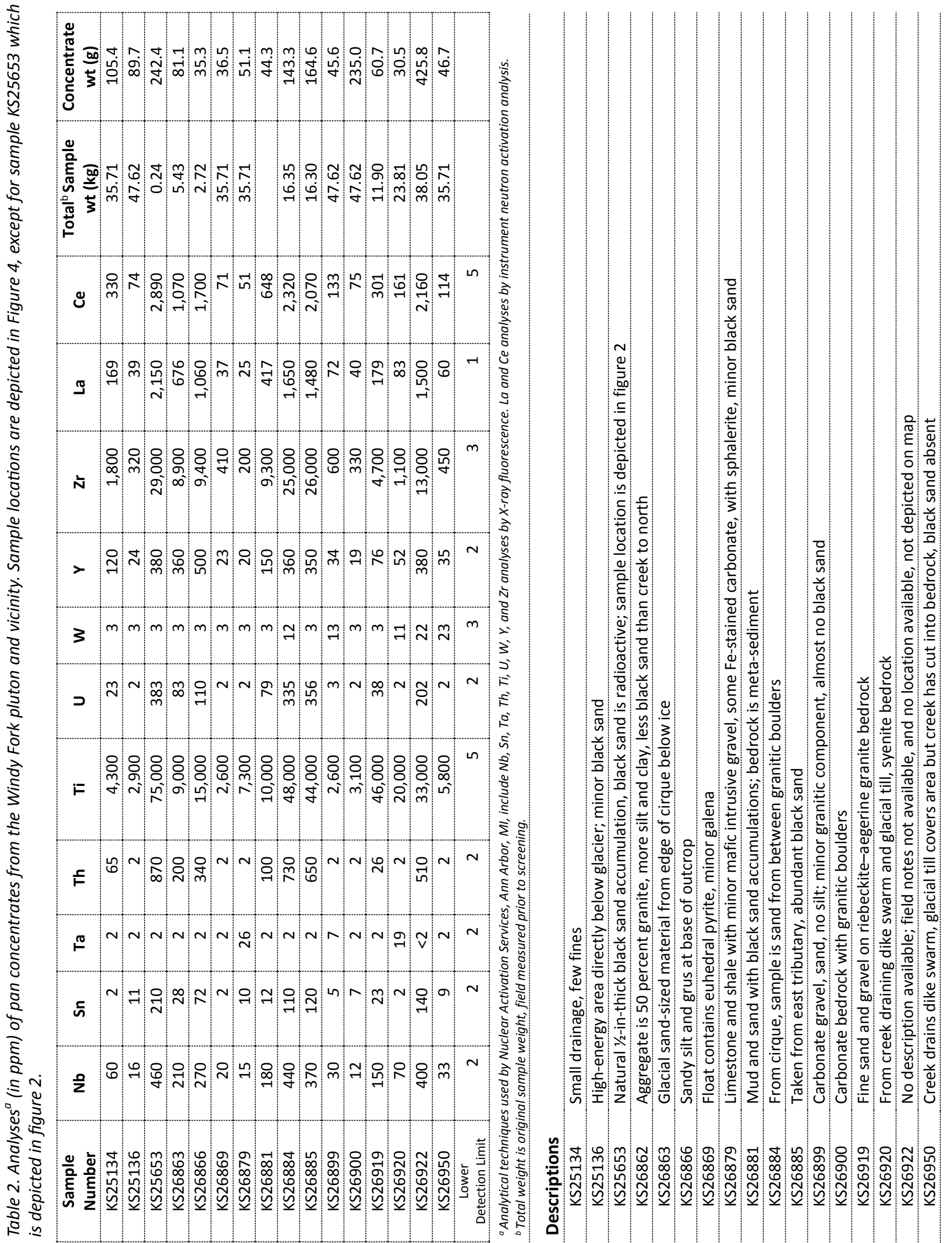


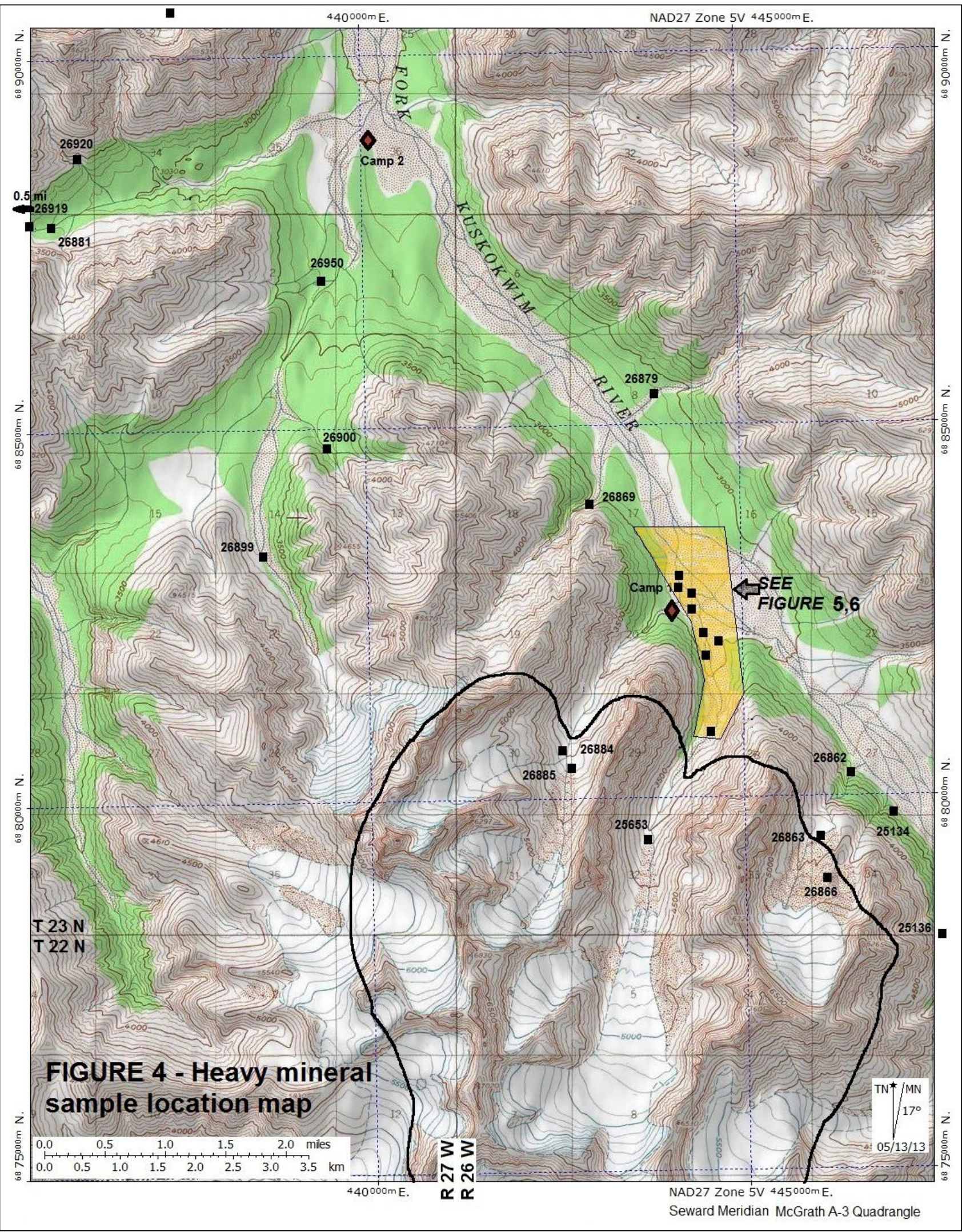

Figure 4. Heavy mineral sample location map. Red diamonds with black outlines mark the locations of camps used during fieldwork; black squares with sample numbers show sample locations. Yellow shaded area shows area of figures 5 and 6. Black line records approximate north margin of the Windy Fork pluton. Sample descriptions and analytical data are listed in table 3. 


\section{METHODS}

Fluvial features were sampled by screening and panning measured volumes of gravel. The gravel was screened at 2 mesh $(0.5$ in) and 16 mesh $(1 \mathrm{~mm})$ and panned to about 50 percent of the -16 mesh volume. For larger bulk gravel samples (table 3 ), the partially concentrated sands were then further processed on a Wilfley table to recover the heavier black sands, which were dried, weighed, and split. An unknown amount of very-fine-sized heavy mineral was observed to be unrecoverable by this single-step tabling and was subsequently lost into tailings. One-half of the concentrate was analyzed by Nuclear Activation Services, Ann Arbor, Michigan, and the other half is currently archived at the DGGS Geologic Materials Center, Anchorage, Alaska). Table 2 lists the analytical methods, detection limits, and results for heavy mineral sampling. Quality control check assays and expanded REE analyses were completed at the USBM Albany Research Laboratory, Albany, Oregon (appendix B), and analytical results were found to be consistent with analyses provided in tables 2 and 3.

Grade calculations for samples from the alluvial outwash fan (fig. 5) were made for $\mathrm{Ti}, \mathrm{Zr}$, and $\mathrm{La}+\mathrm{Ce}+\mathrm{Y}$, and compiled in table 3. Volumetric calculations were based on field tests using local gravels in which one loose, wet, cubic yard was calculated to weigh 3,770 lbs. This value was used to calculate grade for the total original sample. Similarly, this weight per cubic yard measurement was used to calculate grade for - 0.5 -inch size fraction. An in-place cubic yard is estimated to equal the weight of about 1.1 loose $\mathrm{yd}^{3}$, or about $4,147 \mathrm{lbs}$.

Table 3. Resource evaluation of the alluvial outwash fan, Windy Fork pluton. Sample locations shown on figures 4 and 5.

\begin{tabular}{|c|c|c|c|c|c|c|c|c|c|}
\hline \multirow{3}{*}{$\begin{array}{l}\text { Sample } \\
\text { Number }\end{array}$} & \multicolumn{3}{|c|}{ Sample and fraction weights } & \multicolumn{6}{|c|}{ Calculated values per cubic yard ${ }^{a, b}$} \\
\hline & \multirow{2}{*}{$\begin{array}{c}\text { Total } \\
\text { wt. } \\
\text { (lbs.) }\end{array}$} & \multirow{2}{*}{$\begin{array}{l}-0.5 \\
\text { inch } \\
\text { (lbs.) }\end{array}$} & \multirow{2}{*}{$\begin{array}{l}\text { Heavy } \\
\text { conc. } \\
\text { (lbs.) }\end{array}$} & \multicolumn{2}{|c|}{$\mathrm{Zr}$} & \multicolumn{2}{|c|}{$\mathrm{Ti}$} & \multicolumn{2}{|c|}{$\mathrm{La}+\mathrm{Ce}+\mathrm{Y}$} \\
\hline & & & & $\%$ & $\mathrm{lb} / \mathrm{yd} \mathrm{d}^{3}$ & $\%$ & $\mathrm{lb} / \mathrm{yd} \mathrm{d}^{3}$ & $\%$ & $\mathrm{lb} / \mathrm{yd}^{3}$ \\
\hline KS25649 & 131 & 30 & 0.43 & 1.7 & 0.21 & 3.6 & 0.45 & 0.38 & 0.05 \\
\hline KS26862 & 92 & 34 & 0.43 & 1.7 & 0.30 & 4.4 & 0.78 & 0.49 & 0.09 \\
\hline KS26871 & 92 & 30 & 0.40 & 2.0 & 0.33 & 5.3 & 0.87 & 0.49 & 0.08 \\
\hline KS26872 & 84 & 46 & 0.94 & 1.3 & 0.55 & 3.3 & 1.39 & 0.40 & 0.17 \\
\hline KS26873 & 97 & 38 & 0.55 & 1.3 & 0.28 & 5.8 & 1.24 & 0.42 & 0.09 \\
\hline KS26887 & 36 & 36 & 0.52 & 2.5 & 1.37 & 6.2 & 3.39 & 0.56 & 0.30 \\
\hline KS26888 & 36 & 36 & 0.18 & 2.8 & 0.53 & 7.1 & 1.34 & 0.57 & 0.11 \\
\hline KS26890 & 30 & & 0.36 & 1.3 & 0.59 & 1.5 & 0.68 & 0.27 & 0.12 \\
\hline KS26891 & 36 & 36 & 0.25 & 2.5 & 0.65 & 5.6 & 1.50 & 0.58 & 0.16 \\
\hline KS26892 & 105 & 36 & 0.37 & 1.1 & 0.15 & 2.3 & 0.31 & 0.34 & 0.05 \\
\hline
\end{tabular}

\section{Descriptions}

KS25649 90 percent granite gravel, no silt; sample taken $100 \mathrm{ft}$ below prominent dike swarm

KS26862 40 percent of aggregate composed of granite, a few heavy mineral streaks on river bar near this dry channel bed

KS26871 Sample from low cut bank along active channel, 50 percent granite, some streaks on nearby sand bar

KS26872 Sample from alluvial fan derived from pluton

KS26873 Random sites from old river channel bed

KS26887 High-energy creek with heavy mineral streaks accumulating on sand bars

KS26888 Unstratified glacial till

KS26890 Heavy mineral layer skimmed off creek bed; too fine to pan

KS26891 Sandy gravel layer in dry river channel

KS26892 Main Windy Fork channel at confluence with canyon tributary 


\section{RESOURCE EVALUATION}

The most significant placer potential is represented by the combined fans of glaciofluvial outwash formed below two creeks draining the approximate northern half of the Windy Fork pluton (fig. 4). A large elongate fan composed mostly of granitic detritus extends downstream at least 0.10 mi from the $\mathrm{NW}^{1 / 4}$ of Sec. $28, \mathrm{~T} 23 \mathrm{~N}$, R26W (figs. 5 and 6). The gravel is well rounded with numerous cobbles and very little silt-sized material at the ground surface. Streaks of black sand are common along river bars for at least another 4 mi downstream of the confluence of the two creeks.

The areal extent of placer REE-Zr enrichment in the outwash fan is indicated by coloration of sediment; heavy minerals occur in lighter-colored gravel dominantly composed of granite, as shown looking to the southeast in figure 6 . Heavy mineral placer deposition continues an unknown distance downstream beyond the limits of present sampling. Based on available information, however, an area of at least 1,670,000 $\mathrm{yd}^{2}$ is mineralized (sub-economic). Assuming an average depth of $10 \mathrm{yds}$, a total inferred resource of about 17 million $\mathrm{yd}^{3}$ is present.

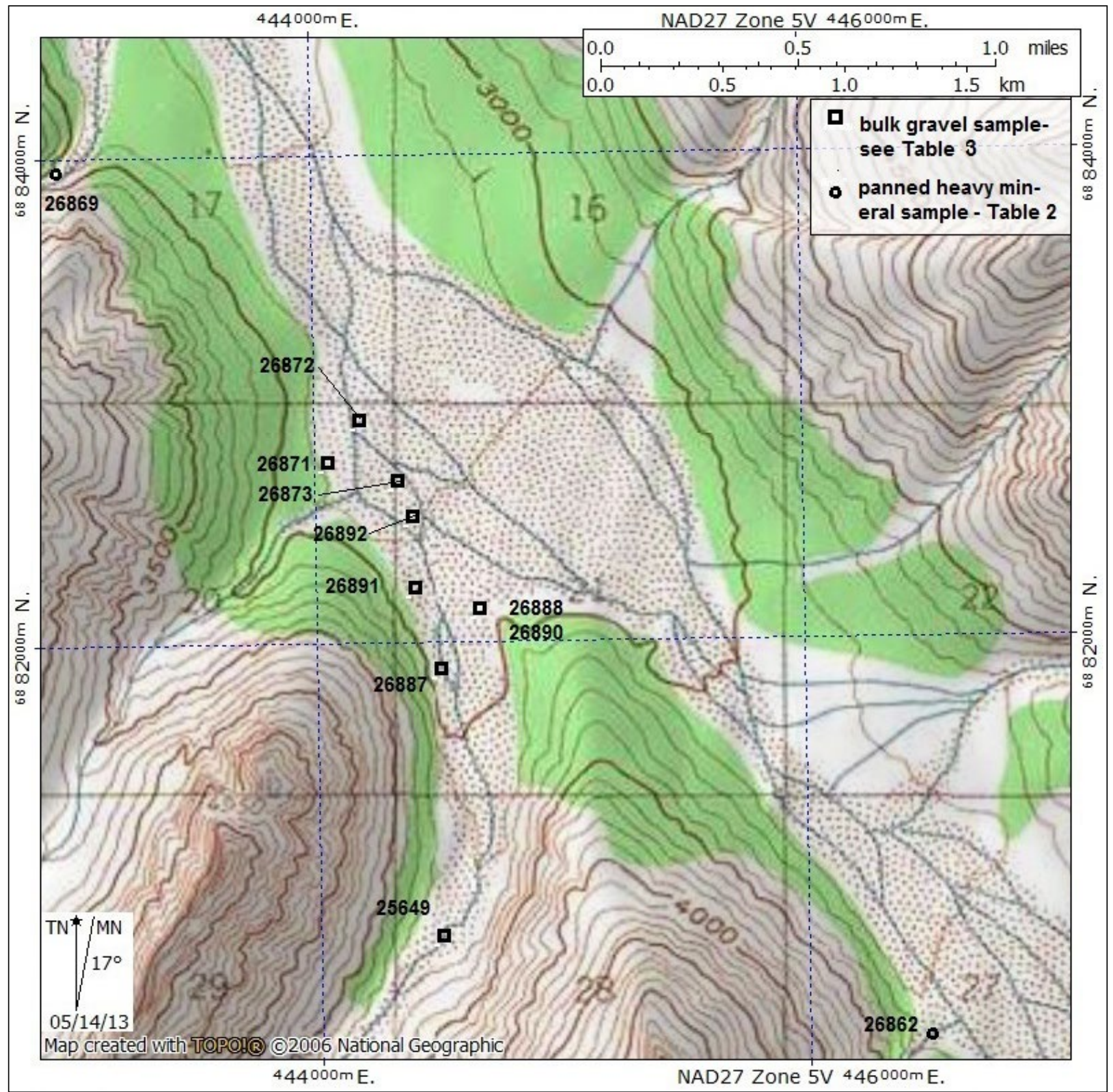

Figure 5. Map of outwash fan with bulk gravel sample locations (empty black squares) and panned heavy mineral sample locations (hollow black circles). Sample descriptions and analytical data are listed in table 3. 


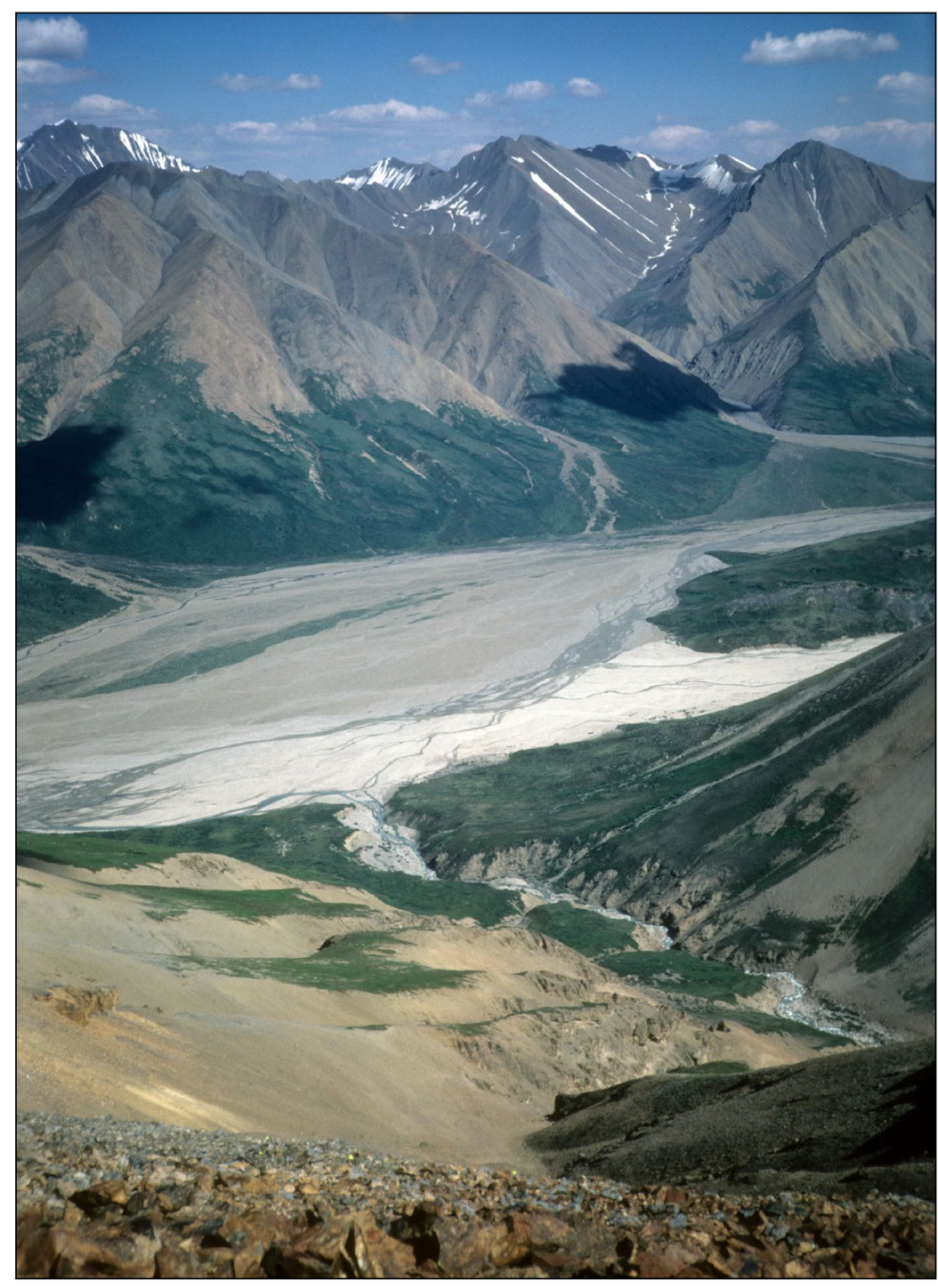

Figure 6. Photograph showing light-colored glaciofluvial outwash fan derived from the northern half of the Windy Fork pluton, as outlined in figure 5. Photo taken facing southeast.

Data listed in table 3 indicate the gravel on the surface of the fan contains 20 to $25 \mathrm{lbs} / \mathrm{yd}^{3}$ of heavy minerals; additional random test panning at the time of the sample collection also confirmed at least this much heavy mineral to be present. Table 3 is a compilation of grade calculations for samples collected from this alluvial fan. It was not possible to test the deposit at depth where higher grade material could potentially exist. Therefore, data indicate grade at the ground surface only and are insufficient to estimate ultimate grade of the deposit.

Samples of the heavy minerals were examined by scanning electron microscope (SEM) ${ }^{2}$. Grains of heavy mineral concentrate (specific gravity greater than 3.6) were mounted on polished sections for study by SEM. Sample splits were made from samples KS26871, KS26891, KS26887, and KS26922. Approximately half of the grains in the samples were composed of heavy minerals. Lighter minerals present include K-Al silicates, a Ca-Fe silicate, quartz, and calcite.

The most abundant heavy mineral grains in the polished sections are ilmenite; titanium is also contained within the rareearth-element-bearing minerals that are present. The second most abundant heavy mineral constituent is zircon, the only zirconium-bearing mineral present in the samples.

The most abundant rare-earth-element-bearing mineral is chevkinite (also tscheffkinite), $\left[(\mathrm{Ca}, \mathrm{Ce}, \mathrm{Th})_{4}\left(\mathrm{Fe}^{+2}, \mathrm{Mg}\right)_{2}\left(\mathrm{Ti}, \mathrm{Fe}^{+3}\right)_{3}\right.$ $\mathrm{Si}_{4} \mathrm{O}_{22}$. It is present primarily as liberated grains between 30 and $100 \mu \mathrm{m}$ in diameter, but is occasionally interlocked with zircon or silicate gangue.

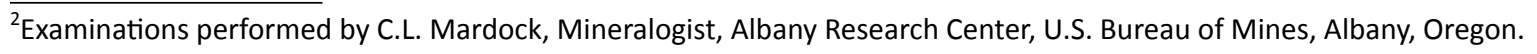


There are lesser amounts of larger $(200 \mu \mathrm{m}$ diameter) grains of rare-earth-element-bearing epidote, allanite or orthite $\left[(\mathrm{Ce}, \mathrm{Ca}, \mathrm{Y})_{2}\left(\mathrm{Al}, \mathrm{Fe}^{+3}\right)_{3}\left(\mathrm{SiO}_{4}\right)_{3}(\mathrm{OH})\right]$ and some 10 - to 25 - $\mu$ m-diameter grains of kainosite $\left[\mathrm{Ca} 2(\mathrm{Y}, \mathrm{Ce})_{2} \mathrm{Si}_{4} \mathrm{O}_{12}\left(\mathrm{CO}_{3}\right) \mathrm{H}_{2} \mathrm{O}\right]$. A few grains of bastnaesite also are present, interlocked with iron oxide. These appear to be of secondary origin and account for only trace amounts of the rare-earth content.

Trace to minor amounts of thorite $\left(\mathrm{ThSiO}_{4}\right)$ occur in the samples. The thorite is altered to a hydrated thorium silicate in some areas. A single grain of uranothorite $\left[(\mathrm{Th}, \mathrm{U}) \mathrm{SiO}_{4}\right]$ was identified.

\section{DISCUSSION}

The northern Windy Fork pluton is composed of peralkaline riebeckite granite similar to that found at Bokan Mountain in Southeast Alaska (Reed and Miller, 1980). Additionally, its physiographic setting is similar, as both plutons are exposed over several thousand vertical feet that are, or were recently, ice-scoured and feature only first-order drainage development.

There are, however, several mineral-resource potential differences observed by the author between the Bokan Mountain and Windy Fork plutons:

Bokan Mountain has a somewhat concentric outer phase of aegirine granite that surrounds an inner riebeckite phase. An altered, weakly mineralized contact zone is mapped between the two phases. At the margin of the Bokan Mountain stock a pronounced border zone and locally mineralized aplite-pegmatite phase is present, indicating a high degree of magmatic differentiation marking the plutonic contact with wall rocks. Within the aegirine phase, numerous steeply dipping, very-late-stage magmatic occurrences grading to early-stage hydrothermal REE mineralization occur as pegmatites, structurally-controlled altered shear zones, vein-dikes, and contact metasomatic deposits. These occurrences commonly contain 0.5 to 5 percent REE. Mineralized vein-dikes also radiate out into the wall rocks for up to $3 \mathrm{mi}$; some of these are currently being explored for commercial development.

In contrast, the northern Windy Fork pluton has a narrow or absent border zone and exhibits minimal internal textural variation. REE-mineralized pegmatites and evidence of any significant volatile-rich, late-stage phases, are lacking.

At Bokan Mountain, accessory lithophile minerals are relatively rare in sediments derived from the pluton. Erosion of highly mineralized but narrow, steeply-dipping structures is inadequate to allow significant heavy mineral concentrations to accumulate. Based on about 150 unpublished heavy mineral concentrate samples collected by the author around the Bokan Mountain granite, only a few grams of heavy mineral will be present in a typical $10 \mathrm{~kg}$ sample of eroded sediments, as compared to an order of magnitude more heavy mineral as recovered in each of the Windy Fork sample sites listed in tables 2 and 3. The widespread occurrence of heavy minerals at Windy Fork suggests widespread, though low-grade, crystallization of the relatively incompatible lithophile elements into disseminated minerals in a size range that reports to gravity separation. At Windy Fork there is no evidence of partitioning of these minerals into economic-scale, late-stage features within the pluton. Thus, the glaciofluvial occurrence of substantial heavy mineral concentrations is present at all Windy Fork sites that were sampled.

In summary, and based on the present evidence, the apparent lack of magmatic differentiation and associated localized volatile concentration in the northern Windy Fork pluton suggests little economic potential for significant lode deposits, but is favorable for potential placer formation. The reverse is true for Bokan Mountain.

\section{REFERENCES}

Gilbert, W.G., and Solie, D.N., 1983, Preliminary geologic map of McGrath A-3 Quadrangle, Alaska: Alaska Division of Geological \& Geophysical Surveys Report of Investigation 83-7, 1 sheet, scale 1:40,000. doi:10.14509/2346

Johnson, N.E., Gunter, M.E., Solie, D.N., and Knowles, C.R., 1990, X-ray and optical data for a rare-earth-poor eudialyte from the north-central Alaska Range: Powder Diffraction, v. 5, no. 2, p. 89-92. doi: $10.1017 /$ S0885715600015402

Reed, B.L., and Lanphere, M.A., 1972, Generalized geologic map of the Alaska-Aleutian Range batholiths showing potassium-argon ages of the plutonic rocks: U.S. Geological Survey Miscellaneous Field Studies Map 372, 2 sheets.

Reed, B.L., and Miller, T.P., 1980, Uranium and thorium content of some Tertiary granitic rocks in the southern Alaska Range: U.S. Geological Survey Open-File Report 80-1052, 7 p.

Solie, D.N., 1983, The Middle Fork plutonic complex, McGrath A-3 Quadrangle, Alaska: Alaska Division of Geological \& Geophysical Surveys Report of Investigation 83-16, 17 p. doi:10.14509/2355

Warner, J.D., and Barker, J.C., 1989, Columbium- and rare-earth-element-bearing deposits at Bokan Mountain, southeast Alaska: U.S. Bureau of Mines Open-File Report 33-89, 201 p. 


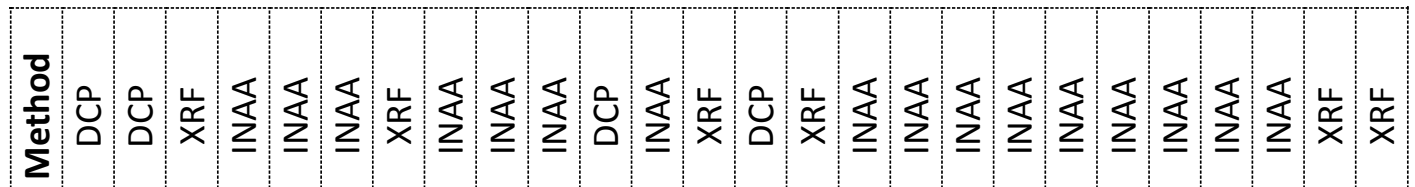

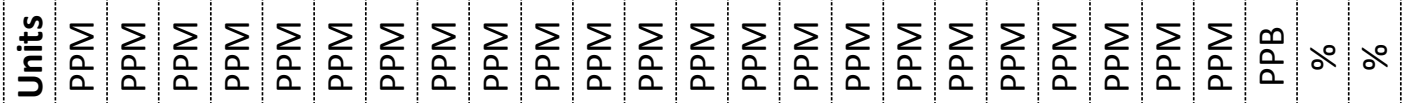

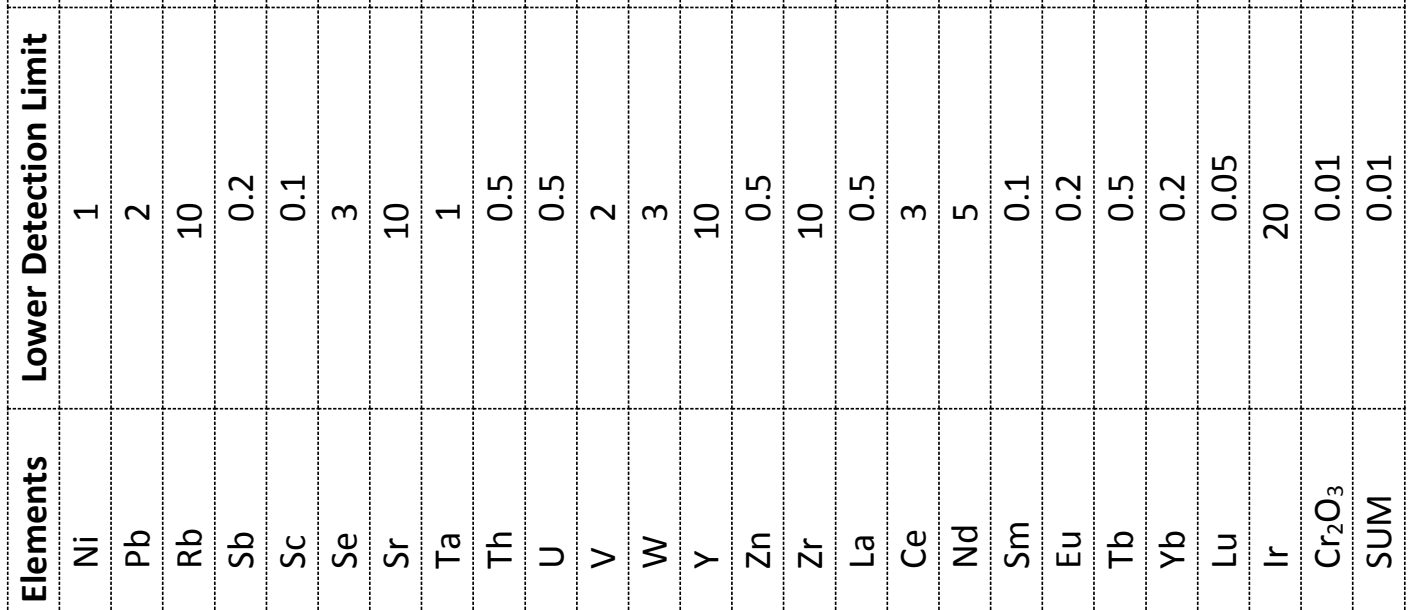

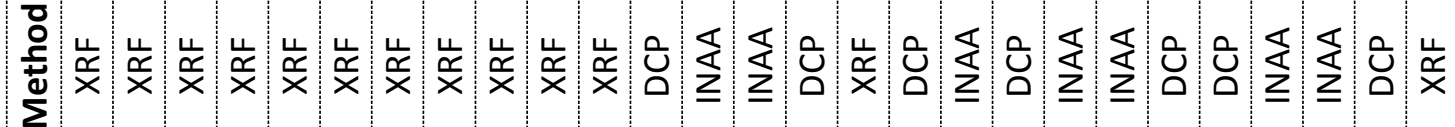

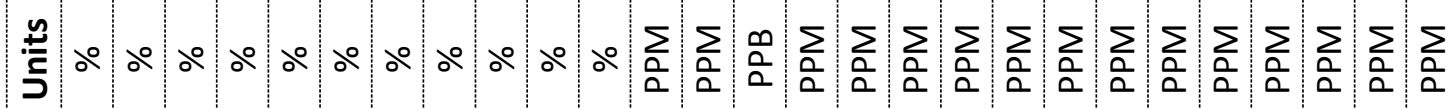

:

.

竎

竞

$\stackrel{n}{\stackrel{2}{c}}$

品 


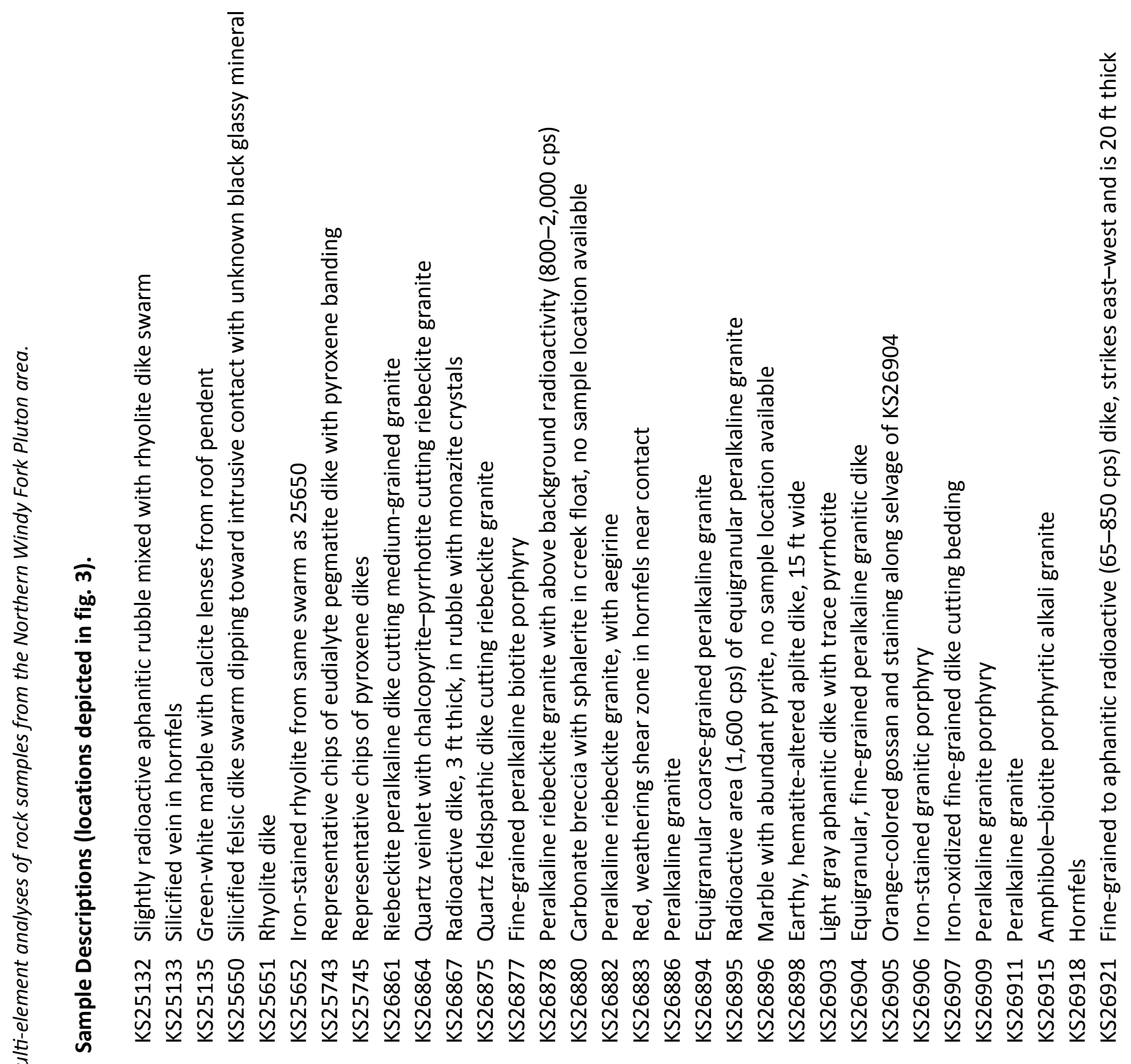


Appendix A (continued). Multi-element analyses of rock samples from the Northern Windy Fork Pluton area. Locations depicted on figure 3, except for samples KS26880 and KS26896 for which smaple locations are not availble.

Date:

31-Oct-88 Report: 631

File Number: 634

NUCLEAR ACTIVATION SERVICES INCORPORATED

\begin{tabular}{|c|c|c|c|c|c|c|c|c|c|c|c|c|c|c|c|c|c|c|}
\hline \multirow[b]{2}{*}{ Element } & \multirow[b]{2}{*}{ Unit } & \multicolumn{17}{|c|}{ SAMPLE NUMBERS } \\
\hline & & KS25132 & KS25133 & KS25135 & KS25650 & KS25652 & KS26861 & KS26864 & KS26875 & KS26877 & KS26880 & KS26882 & KS26883 & KS26894 & KS26896 & KS26906 & KS26909 & KS26921 \\
\hline $\mathrm{SIO}_{2}$ & $\%$ & & & & & & & 71.2 & 76.1 & 75.6 & 13 & 71.6 & 74.6 & 73.8 & 36.7 & 46.4 & 74.6 & 75.4 \\
\hline $\mathrm{AL}_{2} \mathrm{O}_{3}$ & $\%$ & & & & & & & 9.91 & 11.3 & 11.6 & 0.82 & 12.7 & 12.1 & 12.4 & 9.83 & 16.4 & 12.1 & 12.7 \\
\hline CAO & $\%$ & & & & & & & 2.92 & 0.20 & 0.22 & 42 & 0.52 & 0.57 & 0.62 & 17.9 & 10.6 & 0.33 & 0.70 \\
\hline MGO & $\%$ & & & & & & & 0.05 & $<0.01$ & $<0.01$ & 2.87 & $<0.01$ & 0.06 & 0.10 & 5.89 & 6.73 & 0.01 & $<0.01$ \\
\hline $\mathrm{NA}_{2} \mathrm{O}$ & $\%$ & & & & & & & 3.18 & 4.24 & 4.21 & 0.2 & 5.53 & 4.17 & 5.06 & 2.03 & 3.14 & 4.57 & 3.79 \\
\hline $\mathrm{K}_{2} \mathrm{O}$ & $\%$ & & & & & & & 3.90 & 4.16 & 4.45 & 0.14 & 4.92 & 4.73 & 4.58 & 0.15 & 0.55 & 4.57 & 4.43 \\
\hline $\mathrm{FE}_{2} \mathrm{O}_{3}$ & $\%$ & & & & & & & 4.71 & 3.19 & 2.46 & 5.13 & 3.94 & 2.4 & 2.80 & 12.3 & 8.69 & 2.68 & 1.30 \\
\hline MNO & $\%$ & & & & & & & 0.17 & 0.01 & 0.05 & 0.09 & 0.08 & 0.02 & 0.07 & 0.17 & 0.16 & 0.06 & 0.03 \\
\hline $\mathrm{TIO}_{2}$ & $\%$ & & & & & & & 0.19 & 0.11 & 0.11 & 0.02 & 0.28 & 0.22 & 0.23 & 1.31 & 1.52 & 0.19 & 0.10 \\
\hline $\mathrm{P}_{2} \mathrm{O}_{5}$ & $\%$ & & & & & & & 0.03 & 0.02 & 0.01 & 0.02 & 0.02 & 0.03 & 0.04 & 0.15 & 0.43 & 0.02 & 0.02 \\
\hline LOI & $\%$ & & & & & & & 1.77 & 0.93 & 0.93 & 34.9 & 0.62 & 0.77 & 0.54 & 12.6 & 5.39 & 0.77 & 1.08 \\
\hline $\mathrm{CR}_{2} \mathrm{O}_{3}$ & $\%$ & & & & & & & 0.02 & 0.02 & 0.02 & $<0.1$ & 0.01 & 0.02 & 0.02 & $<0.01$ & 0.02 & 0.01 & 0.01 \\
\hline SUM & $\%$ & & & & & & & 98.20 & 100.5 & 99.80 & 99.30 & 100.6 & 99.90 & 100.4 & 99.10 & 100.2 & 100.0 & 99.60 \\
\hline AG & PPM & & & & & & & 5.5 & $<0.5$ & $<0.5$ & $<0.5$ & $<0.5$ & $<0.5$ & $<0.5$ & $<0.5$ & $<0.5$ & $<0.5$ & $<0.5$ \\
\hline AS & PPM & & & & & & & 110 & 140 & 2 & $<2$ & 32 & 2 & 3 & 4 & 7 & $<2$ & $<2$ \\
\hline $\mathrm{AU}$ & PPB & & & & & & & $<5$ & $<5$ & $<5$ & $<5$ & $<5$ & 8 & $<5$ & 10 & 7 & $<5$ & $<5$ \\
\hline $\mathrm{B}$ & PPM & & & & & & & 30 & 30 & 50 & 10 & 70 & 30 & 40 & 10 & 40 & 20 & 30 \\
\hline BA & PPM & & & & & & & 250 & 140 & 50 & 300 & 60 & 200 & 190 & 110 & 170 & 90 & 180 \\
\hline BE & PPM & & & & & & & 3 & 6 & 3 & $<1$ & 18 & 2 & 19 & 2 & 1 & 1 & $<1$ \\
\hline BR & PPM & & & & & & & 3 & 2 & 2 & 2 & 2 & 3 & 2 & 2 & 2 & 2 & 2 \\
\hline$C D$ & PPM & & & & & & & 6 & $<1$ & $<1$ & 45 & 1 & $<1$ & $<1$ & $<1$ & $<1$ & $<1$ & $<1$ \\
\hline $\mathrm{CO}$ & PPM & & & & & & & 2 & 1 & 2 & 2 & 2 & 2 & 2 & 25 & 13 & 1 & 1 \\
\hline CS & PPM & & & & & & & 3.1 & 1.7 & 3.2 & $<0.5$ & 7.8 & 2.6 & 9.8 & 0.8 & 2.9 & 2.1 & 2.8 \\
\hline CU & PPM & & & & & & & 5,200 & 34 & 18 & 780 & 15 & 20 & 25 & 140 & 38 & 15 & 10 \\
\hline GE & PPM & & & & & & & $<10$ & $<10$ & $<10$ & 10 & 10 & $<10$ & $<10$ & $<10$ & $<10$ & $<10$ & $<10$ \\
\hline $\mathrm{HF}$ & PPM & & & & & & & interfer & interfer & interfer & $<1$ & 47 & 20 & 20 & 3 & 3 & 13 & 5 \\
\hline $\mathrm{MO}$ & PPM & & & & & & & 37 & $<5$ & $<5$ & $<5$ & $<5$ & $<5$ & $<5$ & $<5$ & 11 & $<5$ & $<5$ \\
\hline NB & PPM & & & & & & & 50 & 210 & 100 & $<10$ & 150 & 50 & $<10$ & 30 & 10 & 20 & 10 \\
\hline $\mathrm{NI}$ & PPM & & & & & & & 5 & 2 & 3 & 6 & 2 & 4 & 4 & 51 & 17 & 4 & 4 \\
\hline PB & PPM & & & & & & & 280 & 18 & 36 & 6 & 40 & 12 & 20 & 8 & $<2$ & 10 & 20 \\
\hline RB & PPM & & & & & & & 30 & 300 & 460 & $<10$ & 350 & 260 & 270 & 20 & 50 & 210 & 300 \\
\hline SB & PPM & & & & & & & 290 & 3.1 & 1.1 & 0.3 & 1.7 & 1.2 & 2.7 & 1.0 & 2.4 & 1.5 & 0.2 \\
\hline SC & PPM & & & & & & & 0.9 & 0.4 & 0.3 & 2.6 & 0.1 & 0.9 & 1.0 & 25.0 & 25.6 & 0.6 & 0.5 \\
\hline SE & PPM & $<3$ & $<3$ & $<3$ & $<3$ & $<3$ & $<3$ & $<3$ & $<3$ & $<3$ & $<3$ & $<3$ & $<3$ & $<3$ & $<3$ & $<3$ & $<3$ & $<3$ \\
\hline SR & PPM & 30 & 60 & 1,900 & $<10$ & $<10$ & $<10$ & 10 & $<10$ & $<10$ & 620 & $<10$ & $<10$ & 10 & 370 & 790 & $<10$ & 20 \\
\hline TA & PPM & 1 & 1 & $<1$ & 1 & 1 & 9 & 1 & 12 & 5 & $<1$ & 6 & 1 & 2 & $<1$ & 1 & 1 & 2 \\
\hline $\mathrm{TH}$ & PPM & 29 & 26 & 3.3 & 29 & 29 & 43 & 24 & 83 & 21 & 0.7 & 43 & 24 & 550 & 3.4 & 1.3 & 14 & 56 \\
\hline u & PPM & 13.2 & 8.9 & 3.3 & 10.6 & 10.3 & 69.9 & 23.1 & 29.0 & 23.2 & $<0.5$ & 21.5 & 9.0 & 20.8 & 1.1 & 2.7 & 5.1 & 24.8 \\
\hline v & PPM & 2 & 2 & 62 & $<2$ & $<2$ & 4 & 4 & 4 & 2 & 10 & 22 & $<2$ & $<2$ & 250 & 170 & $<2$ & $<2$ \\
\hline w & PPM & $<3$ & $<3$ & $<3$ & $<3$ & $<3$ & $<3$ & 10 & 6 & $<3$ & $<3$ & $<3$ & $<3$ & 4 & $<3$ & $<3$ & 5 & 4 \\
\hline$Y$ & PPM & 60 & 70 & 10 & 100 & 80 & 150 & $<10$ & 200 & 190 & 10 & 190 & 110 & 160 & $<10$ & 20 & 70 & 70 \\
\hline $\mathrm{ZN}$ & PPM & 18 & 32 & 340 & 81 & 47 & 1,700 & 700 & 26 & 250 & 11,000 & 270 & 140 & 180 & 94 & 53 & 140 & 71 \\
\hline ZR & PPM & 210 & 220 & $<10$ & 230 & 210 & 1,900 & 570 & 890 & 670 & $<10$ & 1,900 & 710 & 860 & 60 & 120 & 550 & 150 \\
\hline LA & PPM & 67.6 & 56.5 & 14.5 & 62.6 & 59.5 & 36.1 & 86.2 & 25.9 & 42.3 & 4.3 & 142 & 76.3 & 119 & 11.8 & 15.2 & 76.3 & 49.8 \\
\hline CE & PPM & 132 & 107 & 28 & 113 & 107 & 86 & 163 & 64 & 97 & 16 & 300 & 146 & 236 & 29 & 37 & 143 & 93 \\
\hline ND & PPM & 40 & 41 & 20 & 45 & 40 & 38 & 66 & 17 & 46 & 12 & 123 & 58 & 60 & 16 & 21 & 54 & 32 \\
\hline SM & PPM & 7.6 & 7.2 & 2 & 7.5 & 7.2 & 10.3 & 11.8 & 6.3 & 10.0 & 2.7 & 22.8 & 11.6 & 13.2 & 3.8 & 4.1 & 8.7 & 6.1 \\
\hline EU & PPM & $<0.2$ & $<0.2$ & 0.7 & $<0.2$ & $<0.2$ & $<0.2$ & 0.3 & 0.3 & $<0.2$ & 1.1 & 0.6 & $<0.2$ & 0.4 & 1.0 & 1.3 & $<0.2$ & $<0.2$ \\
\hline TB & PPM & 1.8 & 1.6 & $<0.5$ & 1.5 & 1.4 & 2.9 & 2.4 & 2.9 & 2.7 & $<0.5$ & 4.2 & 2.2 & 2.9 & 0.8 & 0.5 & 1.4 & 1.0 \\
\hline YB & PPM & 5.5 & 5.2 & 1.0 & 5.9 & 5.5 & 21.1 & 8.6 & 20.1 & 12.0 & 0.9 & 14.7 & 7.6 & 11.8 & 2.1 & 2.2 & 5.3 & 4.5 \\
\hline LU & PPM & 0.93 & 0.88 & 0.18 & 0.93 & 0.90 & 4.16 & 1.37 & 3.21 & 1.97 & 0.14 & 2.22 & 1.22 & 2.17 & 0.34 & 0.36 & 0.83 & 0.99 \\
\hline IR & PPB & $<20$ & $<20$ & $<20$ & $<20$ & $<20$ & $<20$ & $<20$ & $<20$ & $<20$ & $<20$ & $<20$ & $<20$ & $<20$ & $<20$ & $<20$ & $<20$ & $<20$ \\
\hline $\mathrm{MN}$ & PPM & 56 & 110 & 330 & 240 & 120 & 730 & 910 & 40 & 310 & 630 & 440 & 94 & 440 & 1,100 & 900 & 340 & 120 \\
\hline
\end{tabular}

${ }^{a}$ NAS Inc. data is missing for KS25132, 25133, 25135, 25650, 25652, 26861.

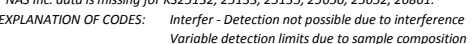


Appendix A (continued). Multi-element analyses of rock samples from the Northern Windy Fork Pluton area.

Date: 3-Nov-88 Report: 638

NUCLEAR ACTIVATION SERVICES INCORPORATED

File Number: 633

SAMPLE NUMBERS

\begin{tabular}{|c|c|c|c|c|c|c|c|c|c|c|c|c|c|c|c|c|}
\hline Element & Unit & KS25651 & KS25743 & KS25745 & KS26867 & KS26878 & KS26886 & KS26895 & KS16898 & KS26903 & KS26904 & KS26905 & KS26907 & KS26911 & KS26915 & KS26918 \\
\hline $\mathrm{SiO}_{2}$ & $\%$ & 74.2 & 68.6 & 46.7 & 74.8 & 73.1 & 72.9 & 74.0 & 68.3 & 67.9 & 73.1 & 75.3 & 75.0 & 71.9 & 71.4 & 74.0 \\
\hline $\mathrm{Al}_{2} \mathrm{O}_{3}$ & $\%$ & 12.6 & 9.85 & 11.2 & 10.6 & 12.1 & 13 & 12.2 & 13.7 & 14.8 & 12.6 & 13.0 & 12.4 & 12.2 & 13.5 & 12.5 \\
\hline $\mathrm{CaO}$ & $\%$ & 0.44 & 1.98 & 9.52 & 0.18 & 0.50 & 0.67 & 0.40 & 1.61 & 1.02 & 0.37 & 0.09 & 0.44 & 0.57 & 1.06 & 0.45 \\
\hline $\mathrm{MgO}$ & $\%$ & 0.01 & 0.18 & 5.49 & 0.08 & 0.08 & 0.18 & 0.09 & 0.29 & 0.15 & $<0.01$ & $<0.01$ & 0.01 & 0.11 & 0.28 & 0.04 \\
\hline $\mathrm{Na}_{2} \mathrm{O}$ & $\%$ & 4.60 & 4.13 & 2.9 & 3.56 & 4.66 & 4.48 & 4.96 & 5.06 & 4.18 & 5.07 & 4.63 & 4.73 & 4.86 & 4.21 & 4.40 \\
\hline $\mathrm{K}_{2} \mathrm{O}$ & $\%$ & 4.96 & 6.82 & 0.41 & 4.77 & 4.59 & 4.75 & 4.56 & 3.55 & 5.36 & 5.08 & 5.08 & 4.80 & 4.65 & 4.91 & 4.94 \\
\hline $\mathrm{Fe}_{2} \mathrm{O}_{3}$ & $\%$ & 1.51 & 6.91 & 16.2 & 2.97 & 2.94 & 2.60 & 2.81 & 3.41 & 3.51 & 2.46 & 0.43 & 1.70 & 3.09 & 2.65 & 1.61 \\
\hline $\mathrm{MnO}$ & $\%$ & 0.01 & 0.01 & $<0.01$ & 0.02 & 0.02 & 0.02 & 0.02 & $<0.01$ & $<0.01$ & 0.02 & $<0.01$ & 0.01 & 0.02 & 0.02 & 0.01 \\
\hline $\mathrm{TiO}_{2}$ & $\%$ & 0.03 & 0.08 & 0.24 & 0.09 & 0.06 & 0.05 & 0.06 & 0.07 & 0.06 & 0.05 & 0.01 & 0.03 & 0.07 & 0.05 & 0.04 \\
\hline $\mathrm{P}_{2} \mathrm{O}_{5}$ & $\%$ & 0.11 & 0.18 & 3.98 & 0.36 & 0.22 & 0.24 & 0.20 & 0.51 & 0.29 & 0.16 & 0.12 & 0.09 & 0.21 & 0.26 & 0.11 \\
\hline LOI & $\%$ & 0.02 & 0.01 & 0.33 & 0.05 & 0.05 & 0.05 & 0.04 & 0.14 & 0.05 & 0.02 & 0.02 & 0.01 & 0.04 & 0.07 & 0.02 \\
\hline $\mathrm{Cr}_{2} \mathrm{O}_{3}$ & $\%$ & 0.70 & 0.70 & 2.47 & 0.93 & 0.85 & 0.54 & 0.54 & 3 & 1.39 & 0.16 & 0.47 & 0.23 & 0.39 & 0.47 & 0.54 \\
\hline SUM & $\%$ & 99.30 & 100.2 & 98.60 & 100.3 & 99.40 & 99.60 & 100.2 & 99.80 & 98.90 & 99.20 & 99.20 & 99.50 & 98.30 & 99.00 & 98.70 \\
\hline $\mathrm{Ag}$ & PPM & $<0.5$ & $<0.5$ & $<0.5$ & $<0.5$ & $<0.5$ & $<0.5$ & $<0.5$ & $<0.5$ & $<0.5$ & $<0.5$ & $<0.5$ & $<0.5$ & $<0.5$ & $<0.5$ & $<0.5$ \\
\hline As & PPM & 4 & 5 & 5 & 10 & 4 & 4 & 5 & 3 & $<2$ & 2 & 8 & 6 & 3 & 3 & 2 \\
\hline $\mathrm{Au}$ & PPB & 6 & $<5$ & 7 & $<5$ & 10 & $<5$ & $<5$ & 10 & $<5$ & $<5$ & $<5$ & $<5$ & $<5$ & 5 & 7 \\
\hline$B$ & PPM & 40 & 80 & 20 & 70 & 40 & 50 & 50 & 70 & 30 & 60 & 50 & 80 & 40 & 50 & 20 \\
\hline $\mathrm{Ba}$ & PPM & 50 & 110 & 540 & 120 & 190 & 350 & 170 & 240 & 470 & 40 & 30 & 30 & 170 & 570 & 50 \\
\hline $\mathrm{Be}$ & PPM & 7 & 10 & 4 & 17 & 13 & 7 & 8 & 6 & 4 & 5 & 6 & 7 & 11 & 7 & 8 \\
\hline $\mathrm{Br}$ & PPM & 2 & 3 & 1 & 2 & 2 & 3 & 2 & 3 & 2 & 1 & 2 & 2 & 1 & 2 & 2 \\
\hline $\mathrm{Cd}$ & PPM & $<1$ & $<1$ & 2 & $<1$ & $<1$ & $<1$ & 1 & $<1$ & 1 & $<1$ & $<1$ & $<1$ & $<1$ & $<1$ & $<1$ \\
\hline Co & PPM & 1 & 2 & 38 & 4 & 2 & 3 & 2 & 4 & 2 & 1 & 1 & 2 & 2 & 2 & 2 \\
\hline $\mathrm{Cs}$ & PPM & 5.3 & 5.2 & 7.7 & 6.2 & 12.7 & 6.7 & 8.0 & 1.7 & 1.6 & 4.9 & 6.1 & 7.6 & 3.8 & 8.7 & 6.5 \\
\hline $\mathrm{Cu}$ & PPM & 25 & 22 & 320 & 19 & 19 & 17 & 13 & 11 & 14 & 21 & 16 & 15 & 13 & 13 & 15 \\
\hline $\mathrm{Ge}$ & PPM & $<10$ & 20 & 30 & 30 & $<10$ & 10 & 10 & $<10$ & $<10$ & $<10$ & $<10$ & $<10$ & $<10$ & $<10$ & $<10$ \\
\hline $\mathrm{Hf}$ & PPM & 10 & 140 & 6 & 410 & 19 & 14 & 22 & 11 & 12 & 7 & 9 & 8 & 21 & 11 & 10 \\
\hline Mo & PPM & 5 & $<5$ & $<5$ & $<5$ & $<5$ & $<5$ & $<5$ & 7 & $<5$ & $<5$ & 5 & $<5$ & $<5$ & $<5$ & $<5$ \\
\hline $\mathrm{Nb}$ & PPM & 30 & 50 & 30 & 1300 & $<10$ & 40 & 30 & 40 & 20 & 20 & 20 & 30 & 40 & 30 & 40 \\
\hline $\mathrm{Ni}$ & PPM & 4 & 5 & 62 & 6 & 5 & 4 & 4 & 4 & 5 & 4 & 3 & 3 & 3 & 6 & 3 \\
\hline $\mathrm{Pb}$ & PPM & 20 & 28 & 8 & 44 & 88 & 22 & 10 & 18 & 16 & 14 & 18 & 30 & 20 & 16 & 18 \\
\hline $\mathrm{Rb}$ & PPM & 240 & 450 & $<10$ & 480 & 330 & 220 & 270 & 150 & 150 & 220 & 260 & 260 & 270 & 240 & 280 \\
\hline $\mathrm{Sb}$ & PPM & 0.9 & 0.9 & 0.7 & 8.3 & 1.9 & 1.3 & 1.5 & 0.6 & 0.3 & 1.1 & 1.3 & 1.4 & 1.4 & 1.2 & 0.4 \\
\hline $\mathrm{Sc}$ & PPM & 1.5 & 1.4 & 36.2 & 0.2 & 0.7 & 1.8 & 1.3 & 2.6 & 1.7 & 0.2 & 0.9 & 1.5 & 1.0 & 2.7 & 1.4 \\
\hline Se & PPM & $<3$ & $<3$ & $<3$ & $<3$ & $<3$ & $<3$ & $<3$ & $<3$ & $<3$ & $<3$ & $<3$ & $<3$ & $<3$ & $<3$ & $<3$ \\
\hline $\mathrm{Sr}$ & PPM & $<10$ & 190 & 300 & 50 & 10 & 50 & $<10$ & 70 & 80 & $<10$ & $<10$ & $<10$ & $<10$ & 90 & $<10$ \\
\hline $\mathrm{Ta}$ & PPM & 2 & 14 & 1 & 80 & 3 & 1 & 4 & 2 & 1 & $<1$ & 1 & 1 & 2 & 1 & 2 \\
\hline \begin{tabular}{|l|} 
Th \\
\end{tabular} & PPM & 26 & 21 & 1.2 & 880 & 580 & 25 & 220 & 37 & 11 & 17 & 22 & 22 & 36 & 22 & 27 \\
\hline $\mathrm{U}$ & PPM & 8.8 & 13.6 & $<0.5$ & 277 & 30.0 & 9.2 & 16.3 & 15.8 & 5.7 & 4.6 & 13.7 & 9.9 & 10.6 & 9.2 & 9.9 \\
\hline $\mathrm{V}$ & PPM & 8 & 10 & 530 & 12 & 12 & 16 & 14 & 22 & 14 & 8 & 6 & 8 & 10 & 18 & 6 \\
\hline W & PPM & $<3$ & 6 & $<3$ & 14 & 4 & $<3$ & $<3$ & 4 & $<3$ & $<3$ & $<3$ & $<3$ & $<3$ & $<3$ & $<3$ \\
\hline$Y$ & PPM & 40 & 270 & 20 & 1400 & 390 & 80 & 120 & 70 & 50 & 60 & $<10$ & 70 & 120 & 60 & 70 \\
\hline $\mathrm{Zn}$ & PPM & 49 & 160 & 140 & 200 & 220 & 95 & 270 & 110 & 95 & 140 & 27 & 64 & 170 & 62 & 80 \\
\hline $\mathrm{Zr}$ & PPM & 310 & 4900 & 250 & 9600 & 910 & 540 & 840 & 330 & 550 & 280 & 220 & 170 & 820 & 400 & 280 \\
\hline La & PPM & 47.0 & 52.2 & 11.6 & 416 & 361 & 68.2 & 182 & 94.9 & 44.4 & 81.6 & 14.6 & 51.8 & 118 & 60.8 & 63.8 \\
\hline $\mathrm{Ce}$ & PPM & 87 & 131 & 34 & 914 & 670 & 114 & 284 & 152 & 89 & 141 & 29 & 104 & 223 & 117 & 117 \\
\hline $\mathrm{Nd}$ & PPM & 27 & 46 & 25 & 404 & 192 & 49 & 86 & 55 & 36 & 61 & 11 & 45 & 67 & 48 & 45 \\
\hline $\mathrm{Sm}$ & PPM & 5.4 & 14.1 & 5.3 & 104 & 39.6 & 7.6 & 13.3 & 9.7 & 6.7 & 8.0 & 1.8 & 7.8 & 13.4 & 7.5 & 7.3 \\
\hline Eu & PPM & $<0.3$ & $<0.3$ & 2 & 1.3 & 0.4 & $<0.5$ & 0.5 & 0.9 & 0.3 & 0.4 & $<0.2$ & $<0.2$ & 0.4 & 0.4 & $<0.2$ \\
\hline $\mathrm{Tb}$ & PPM & 1 & 3.7 & 1.0 & 34.2 & 7.5 & 1.7 & 2.0 & 1.6 & 1.3 & 0.9 & 0.5 & 1.2 & 2.6 & 1.5 & 1.5 \\
\hline $\mathrm{Yb}$ & PPM & 4.4 & 23.4 & 3.4 & 137 & 31.0 & 6.1 & 10.2 & 5.7 & 4.1 & 4.6 & 2.1 & 4.7 & 9.5 & 4.5 & 5.9 \\
\hline Lu & PPM & 0.73 & 3.69 & 0.47 & 20.1 & 4.81 & 0.94 & 1.81 & 0.95 & 0.67 & 0.71 & 0.56 & 0.75 & 1.45 & 0.80 & 0.89 \\
\hline \begin{tabular}{|l|} 
Ir \\
\end{tabular} & PPB & $<20$ & $<20$ & $<20$ & $<20$ & $<20$ & $<20$ & $<20$ & $<20$ & $<20$ & $<20$ & $<20$ & $<20$ & $<20$ & $<20$ & $<20$ \\
\hline $\mathrm{Mn}$ & PPM & 210 & 430 & 1800 & 360 & 370 & 350 & 400 & 450 & 380 & 380 & 60 & 170 & 490 & 330 & 250 \\
\hline
\end{tabular}

EXPLANATION OF CODES: VARIABLE DETECTION LIMITS DUE TO SAMPLE COMPOSITION 


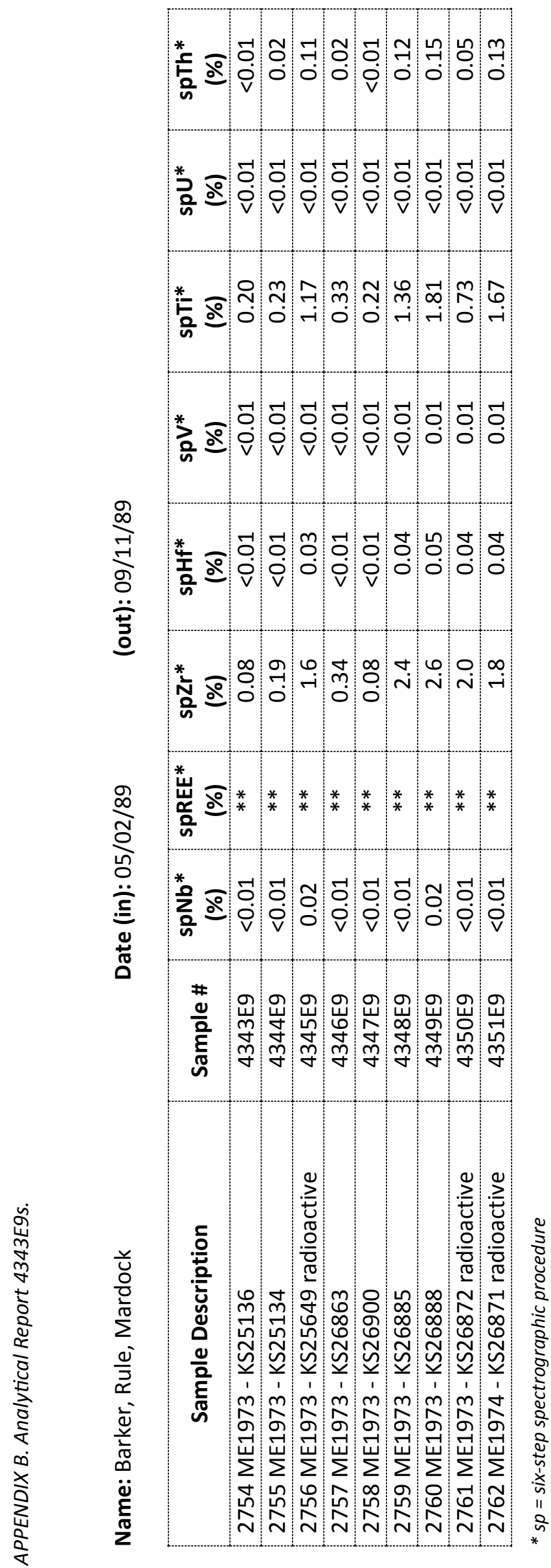

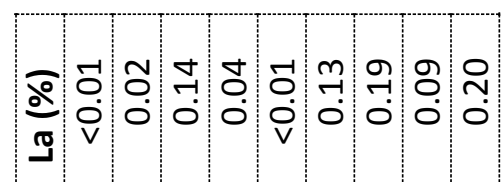

रे

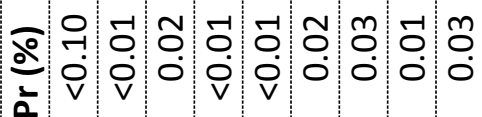

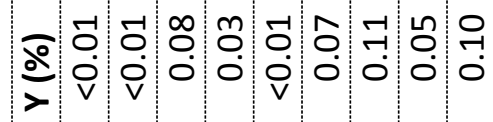

光

J)

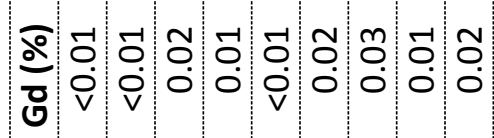

아일

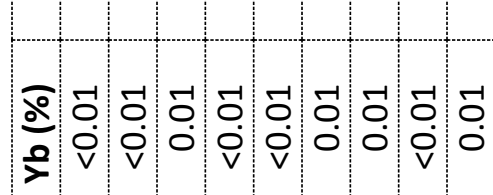

ஓ E 